
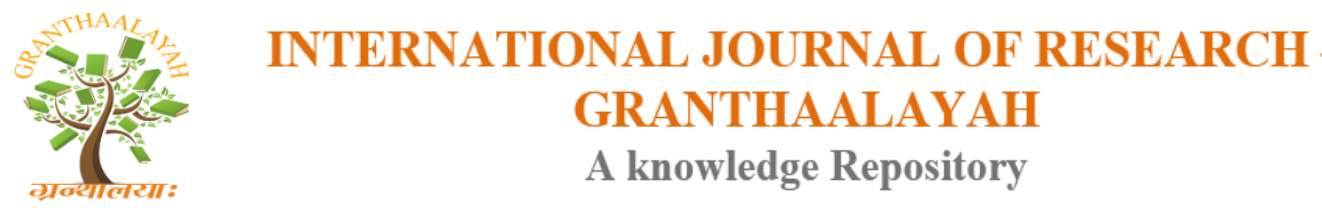

\title{
Social
}

\section{YADI NAASTI DAIVAM- A PRINCIPLE OF PREVIOUS LIFE'S DEEDS}

\author{
Dr. Nishi Arora ${ }^{1}$, Dr. Nidhi Shrivastava ${ }^{2}$ \\ ${ }^{1}$ Associate Professor \& HOD, Maulik Siddhant and Samhita Department, A \& U Tibbia College \\ \& Hospital, New Delhi, India \\ ${ }^{2}$ Reader and HOD, Rachana Shaarira Department, Govt. Ayurveda College \& Hospital (Auto) \\ Jabalpur, MP, India
}

\begin{abstract}
It is commonly observed all throughout history, felt all throughout our lives, that often, the achievements gained by people are not really tantamount to the amount of effort they have put in to try to achieve the same. This raises doubts on the saying 'Hard work is the key to success' as some people don't work hard at all but achieve greater than those who have bet their lives on the same goal. To these conflicts that arise in our minds, causing depression and anxiety symptoms in some people can all be answered by a quarter of a verse found in the ancient text of Ayurveda, Charak Samhita. It also provides reasoning and solutions about the daily conflicts in society to some extent. Six principles were extracted from the same quarter of the verse by the author. It was concluded that people should: remain in present time and perform duties with utmost of precaution, not get discouraged by failures as they do not always imply that their present actions are incorrect, keep in mind that what they get is due to the balance of duties that they have performed, remember that whether the duties were performed in present or past, no one else is responsible for anyone else's agony or pleasure.
\end{abstract}

Keywords: Karma; Daiva; Paurush.

Cite This Article: Dr. Nishi Arora, and Dr. Nidhi Shrivastava. (2018). "YADI NAASTI DAIVAM- A PRINCIPLE OF PREVIOUS LIFE'S DEEDS." International Journal of Research - Granthaalayah, 6(6), 357-360. https://doi.org/10.29121/granthaalayah.v6.i6.2018.1380.

\section{Introduction}

All of us work (Karma) and it is primarily mandatory to do so. Some of these may be voluntary and others may be involuntary, but it is a universal truth that a living creature cannot stay alive without work even for a fraction of a second ${ }^{1}$. It is also known in other forms such as Yatna, Prayatna, Pravritti etc. ${ }^{2}$ Another textual fact is that even a foolish person does not indulge in any Karma without any reason or goal. ${ }^{3}$

Overviewing this subject, a few questions naturally arise in our minds such as 'Do all our Karmas lead to success?' or 'Can hard work really guarantee achievements?' the answer is often 'NO'. 
Another query which arises in our minds is that 'Sometimes a goal can succeed in barely minimum effort whereas sometimes the same goal is not achieved even by the utmost of genuine effort'

To answer these questions, Charak Samhita (An authentic Ayurveda text) has provided the foundation to this train of thought. This text is a comprehensive place for every kind of knowledge in this world as is claimed by the text itself. ${ }^{4}$

The aim of the author in this article is to explain a part of a verse from second chapter of Sharira Sthan of Charak Samhita. The purpose of this article is to satisfy the above posed questions about the deeds, their efficacy and their ultimate results.

\section{Materials and Methods}

The Verse- "Stayaashraye vaa dwiwidth yathokte poorvam gadebyoh pratikarma nityam Jitendriam naanuptanti rogaastatkaalyuktam yadi naasti daivam. (Charak Shaarirasthaan-2/43) The Context- Through this verse, the Samhita intends to teach us about the 'Prevention of diseases'. This verse re-imposes the fact that diseases only develop in two areas, body and mind. Diseases may be counteracted by following the principle of Pratikarma Nitya (Remaining alert regarding health). It says that people who remain mindful about their actions and how these could affect their lives along with discarding anything that is harmful to the body can never get ill, on the condition that their previous lives' deeds do not hamper them. (Yadi naasti daivam)

\section{Description}

The expansion of a quarter of this verse (Yadi naasti daivam) gives us six distinct principles.

1) Dwividh karma ke madhyam se punarjanm ki pushti- Confirmation of rebirth through two types of karma. There are two types of karma, one being Daiva (Deeds of previous life) and the other being Paurush (Deed of current life). ${ }^{5}$ Not only this, but in the very next line, Aacharya explains the role of these two types of karmas in the prevention of any disease. When Daiva and Paurush are mutually against our well- being, diseases normally occur and when these are in favour, then diseases hardly occur. ${ }^{6}$

2) Karma naaanyadapekshate- Karmas do not depend on anything. While describing the nature of karmas, the specifics regarding it are also prevalently told. This principle tells us that duty itself is a karma and it neither does it depend on anything else nor does it get interrupted or changed by any other factor. ${ }^{7}$ You reap what you sow, even if what you sowed was during your previous life. Additionally, self- control is the basis of all Karmas and hence it denies the external locus of control.

3) Karma vipaak kaal- Time of Ripening of the Karma. It is told through this principle that not all the karmas show their effect immediately. The nature of the karma along with its intensity decides the point of time in which its effect will be visible. ${ }^{8}$ It's like a fruit being ripened with variable amounts of nutrition and sunlight. But, there is no Karma which remains fruitless, though some effects may be so subtle that they are not able to be noticed. ${ }^{9}$ Karmas are attached to the souls, always there even when nullified by time or opposite Karmas and thus transfer over to another body when the soul is rebirthed.

4) Daivam purushkarena durbalam hhyuphanyate- The powerful wins. ${ }^{10}$ Here, the principle of bhuyastoo vyapdeshaha is also being explained indirectly. Fortune of a person 
is decided by whichever of his/her two types of karmas is stronger in intensity. This type of teaching may look very contradictory because it will naturally deter people from improving themselves, blaming all their bad luck on their previous life's karmas but the Samhita itself tries very hard to make it known that no matter how bad your karmas may be in previous or current life, they can still be affected by your present and future actions, and that by working hard on improving our actions we can still head to a better future, thus encouraging people to look back at their life, stop what they were doing wrong, and start initiating better actions.

5) Aatmanammaeve manyeta kartaaram sukh dukhayoho- Understanding that your fortune is due to your own deeds. ${ }^{11}$ This principle is based on the fact that your actions are in your own hands. You may opt to live your life peacefully, eating healthy and harmless foods, keeping your surroundings clean etc. But on the same note, you can also choose to live your life miserably, get into fights, eat unhealthy and harmful foods, make your surroundings unclean and filthy etc. These are all choices which we ourselves can make and these choices and actions themselves decide our fortune. Thus, blaming anybody else for forcing/influencing/tricking us to do inappropriate things is useless. Once a person understands this principle in its whole, he/she will not indulge in any kind of blame-game and hence can be away from the conflictive situations and various arbitrary thoughts. It helps in cognitive restructuring.

6) Kritasya karmanaha phalam na akritasya- You only get affected by the things you have done and not the things that you haven't. ${ }^{12}$ The responsibility of your actions and deeds are yours and yours only. Thus, there cannot be any case where you are bearing the effects of other's fortunes.

\section{Conclusion}

1) Remain in present time and perform duties with utmost of precaution.

2) Failures do not always imply that your present actions are incorrect.

3) It's always to be kept in mind that what you get is due to the balance of duties that you have performed, whether they be of present or past.

4) No one else is responsible for anyone else's agony or pleasure. We all only reap what we have already sown.

\section{References}

[1] Swami Prabhupaad (1990) Bhagwad Gita, Ch-3/5

[2] Banwaari Lal Gaur (2014, August 1) Hindi Translation of Chakrapani commentary on Charak Samhita, Charak Vimaan Sthan, Ch-8/77

[3] Banwaari Lal Gaur (2014, August 1) Hindi Translation of Chakrapani commentary on Charak Samhita, Charak Shaareer Sthan, Ch-1/78

[4] Banwaari Lal Gaur (2014, August 1) Hindi Translation of Chakrapani commentary on Charak Samhita, Charak Siddhi Sthan, Ch-12/54

[5] Banwaari Lal Gaur (2014, August 1) Hindi Translation of Chakrapani commentary on Charak Samhita, Charak Shaareer Sthan, Ch-2/44

[6] Banwaari Lal Gaur (2014, August 1) Hindi Translation of Chakrapani commentary on Charak Samhita, Charak Shaareer Sthan, Ch-2/44 
[7] Banwaari Lal Gaur (2014, August 1) Hindi Translation of Chakrapani commentary on Charak Samhita, Charak Sutra Sthan, Ch-1/52

[8] Banwaari Lal Gaur (2014, August 1) Hindi Translation of Chakrapani commentary on Charak Samhita, Charak Sutra Sthan, Ch-11/40

[9] Banwaari Lal Gaur (2014, August 1) Hindi Translation of Chakrapani commentary on Charak Samhita, Charak Shaareer Sthan, Ch-1/117

[10] Banwaari Lal Gaur (2014, August 1) Hindi Translation of Chakrapani commentary on Charak Samhita, Charak Vimaan Sthan, Ch-3/33

[11] Banwaari Lal Gaur (2014, August 1) Hindi Translation of Chakrapani commentary on Charak Samhita, Charak Nidaan Sthan, Ch-7/21

[12] Banwaari Lal Gaur (2014, August 1) Hindi Translation of Chakrapani commentary on Charak Samhita, Charak Sutra Sthan, Ch-11/32

*Corresponding author.

E-mail address: nishiarora_doc@yahoo.co.in 